\title{
THE UK SNAGGING PROCESS: A BENCHMARK FOR RESIDENTIAL CONSTRUCTION
}

\author{
FUNMILAYO EBUN ROTIMI $^{1}$, JOHN TOOKEY ${ }^{2}$ and JAMES OLABODE ROTIMI ${ }^{3}$ \\ Construction Management Programme, School of Engineering, Auckland University of \\ Technology, Private Bag 92006, Auckland, New Zealand. \\ ${ }^{1}$ frotim@aut.ac.nz \\ 2jtookey@aut.ac.nz \\ j3rotimi@aut.ac.nz
}

\begin{abstract}
The residential construction sector is under pressure to meet an ever increasing customer expectation of quality improvement on their development projects. But not all completed residential projects turn out on a clean slate and these have become a source of concern to homeowners and approving authorities. Recent study provides evidence that a significant percentage of new homeowners call back their developers to rectify snags and latent defects. Therefore this paper is undertaken to provide a benchmark for the implementation of a snagging process similar to the UK for the residential sector in New Zealand. The methodology adopted is a meta-study of published literature relating to snagging practice in the UK. This is compared with existing building inspection practice in New Zealand and improvement areas systematically identified. It is hoped that the study would benefit the entire construction industry by serving as improvements to quality performance in residential construction in New Zealand.
\end{abstract}

Keywords: Benchmarking, UK, New Zealand, residential construction sector, snagging process.

\section{Introduction}

The construction industry is an important bellwether and stimulus for the New Zealand economy, as it contributes about $5 \%$ of total Gross Domestic Products (GDP) (Alan, Yin, \& Scheepbouwer, 2008). The sector has significant social and economic relevance, since it generates employment, induces development in other economic sectors through the multiple effects of investment in buildings (Pedro, Meijer, \& Visscher, 2008). The residential housing sector is one of three distinct sub-systems in the New Zealand construction industry. In a typical year, residential housing construction accounts for approximately 24,000 new builds and 32,000 renovations to existing homes (Building and Construction Sector Productivity Taskforce, 2009). This places residential housing centrally in any economy and an important sector in every national development plan. The relevance of the residential housing sector therefore means that any performance improvement of the sector will translate to benefits to the general economy. Therefore the current paper focuses on the need to reduce snags and latent defects in residential buildings as a way of improving quality performance of building developers and in consequence productivity of the sector. There is little doubt that proper quality management systems within construction organisations and 
their productivity are positively related (Page, 2010).

'Snags' and 'snagging' is gradually becoming terms used in construction environments outside the UK construction industry which was the origin of this terminology. Snagging items are quality failure items that are identified near the completion stage of a construction project by an individual who could be termed as 'the snag identifier', while the process of identifying and rectifying these quality failures is known as snagging or building inspection (Sommerville, Craig, and Bowden, 2004). Snagging describes the process of checking for faults or defects in a property and correcting them before the property is handed over to a new owner. 'Snagging' problems in this context are items of work that still require some degree of attention after the main body of work has been completed (Craig 2008).

The common terminology for 'snags' is 'defects' while a 'snag identifier' will mostly likely be referred to as a 'building inspector' in New Zealand. Building inspection appears to be common practice for new and existing buildings in the housing sector in the UK. Although in New Zealand at present, inspections for defects and repairs are mostly carried out for old and existing buildings. Inspection has become almost a standard presale clause for older residential buildings in New Zealand. Capturing defects that occur before or after handover of new residential buildings is rare in New Zealand. This study therefore intends to create awareness for improved snag reporting in new residential buildings in New Zealand, believing there are valuable lessons to be learnt from this UK practice. According to Brennan (2004) snagging provides an opportunity for problem areas to be remedied when a home buyer still has the builder over a barrel.

\section{Literature Review}

\subsection{Quality and the construction industry}

Quality improvement has been identified as one of a number of initiatives to assist in the drive for major improvements in the construction industry. Latham Report (1994) and the Egan Report (1998) were two major reports that suggested performance improvement in the construction industry. The Latham report for example outlined improvements which emphasises early customer involvement so that customer requirements are established from project outset. The Egan report on the other hand identified the need for a consistent reduction in the level of defects by proposing an annual reduction of $20 \%$ in the levels of defects discovered in construction projects in the UK. Though the Egan report has been criticised by several studies as being short of factual evidences with little benchmark figures of current defect levels that the industry could work towards reducing, the authors believe that the Egan report provide a broad base on which subsequent studies can build on. Further, though there is no substantial evidence to show how figures were generated, the authors believe that there could be shared benefits from improved performance if clear measurable targets and specific milestones are set towards productivity improvement.

Poor quality practices and non-conformance to quality standards result in unnecessary costs associated with defects and reworks that are damaging to the construction industry. For the past two decades, researchers have tried to give estimated costs required to carry out work that was not correctly done. For example Hammalund et al. (1990a; 1990b) found that the cost of repairing quality failure items is $6 \%$ of the total production costs. Burati et al (1992) revealed that the cost of defect rectification varies between 0.4 and $26.0 \%$ of total project costs resulting in an average cost at $12.4 \%$. Josephson and Hammerlund (1999; 1994) studies show that the costs of defects 
vary between 2.3 and $9.4 \%$ of the total production costs, this only includes the direct costs of defects. Around the same period, Abdul-Rahman (1997) estimated costs of nonconformances on constructions sites to be $6 \%$ of total project costs. A study conducted by Love and Li (2000) on Australia construction project gives an estimate of rework cost to be 3.2 and $2.4 \%$ of a project's contract value. Similarly, Barber et al., (2000) study on the costs of quality failures in two major road projects show that that the costs of failure were respectively 3.6 and $6.6 \%$ of the total project costs. These and other studies demonstrate the need to understand how and when defects occur and the possible remedial measures needed to prevent reworks in construction. Additionally the studies establish the need for effective and efficient quality management systems combined with continuous improvement strategies as a way of reducing rework costs (Fayek, Dissanayake, \& Campero, 2004). Thus quality must be fundamental to every design process and defects and snagging need to be 'designed out' before works commence on sites (Egan, 1998). If Egan's suggestion of annual $20 \%$ reduction in defect at handover with an ultimate goal of zero defects is implemented, then completed residential projects will most probably turn out on a clean slate.

Achieving zero defects in residential housing construction is highly desirable but difficult to achieve. Studies show that residential housing construction is beset with high cost of rework and non-conformance to quality standards. A number of reasons could account for this. Griffith (1990) suggests that defective work could be attributed to design, detailing, specification, legislation, coordination, communication, supervision and constructability issues. Love and Sohal (2003) identified poor workmanship as a significant contributor to poor quality on construction projects. Design as a primary cause of rework may be attributed to design changes made by clients and end-user (Love \& Li, 2000). Josephson and Hammarlund (1999) hold alternative views believing that reworks are linked to the activities of project participants and only the coordinated action of these participants can reduce the incidence of rework on projects. Thus collaboration and integration between project participants will invariably minimise reworks in building construction (Abdul-Rahman, 1995). In this light, Atkinson (2002) suggests that developing a management system to address the problem of poor formal communication (transfer and use of information) between project parties could lead considerably to improved performance.

An aspect of good quality management systems in residential housing is an inspection process which should expose potential quality issues before they occur. Inspections would significantly reduce defects at handover (Beattie, 2011) and overall, enable construction organisations to set realistic performance standards and focus efforts where they are most needed

\subsection{New residential buildings in New Zealand}

New Zealand residential construction has undergone significant changes in the past two decades. In 1996, there was a change in the Building Code that allowed the use of untreated timbers for residential buildings in New Zealand. That simple change left between 30,000 and 90,000 homes requiring repairs as a result of weather tightness problem (Beattie, 2011). Though the change was subsequently retracted in 2004, significant and long term damage has been made to the building industry in New Zealand. The weather tightness problem and especially recommendations made within the Hunn's report (Hunn, 2002), prompted the reform of 
the Building Act. The weather tightness problem is not the focus of the current study nevertheless it is a useful reference point to quality problems in buildings in New Zealand. Recently Page (2011) confirms that $60 \%$ of new homeowners call back their developers for one form of defect or another. This and other studies are indicative of a current and pressing need to identify quality defects in the NZ residential construction sector.

The key to quality in the built environment and other value for money initiatives is to demand good management practices on projects (CIC, 2004). Integrating best building inspection practices into the New Zealand construction industry should therefore improve the quality of the projects being delivered. Indeed the current study is equally important in the context of low productivity within the industry as a result of poor building practices.

\section{Benchmarking the snagging process at hand-over}

There is growing interest in the need to improve quality performance levels in the residential construction sector. This search for improvement is driven by a long list of industry wide problems, such as poor inspection processes, unskilled workers, poor workmanship and increase in the number of defects (Beattie, 2011). As a result, governments, approving authorities and professional bodies are looking for new (or at least different) ways of managing house construction process. For example, the UK residential sector experiences low quality performance with a significant record of defects in new builds (Sommerville, 2007). Quality achievement is therefore a problem within the UK construction industry (Craig, 2008; Sommerville, Craig, \& Ambler, 2005; Sommerville \& McCosh, 2006). The severity of non-quality achievement was illustrated in similar studies in Australia (Georgiou, 2000; Ilozor, Okoroh, \& Egbu, 2004; Mills, Love, \& Williams, 2009). The studies confirm that defects are evident in residential buildings and the costs to rectify these defects are enormous. With these myriad of quality problems in residential construction, the current study shares the view that high quality builds cannot always be achieved by relying on the performance of construction parties (Craig, 2008). Hence a firm process for defect identification and rectification should put home owners mind at ease about the final quality of their investments. Consider that seeking redress and identifying accountability is difficult when quality issues arise in residential buildings (Cossar, 2003).

Further the identification of defects may be compromised within current inspection processes. According to Sommerville et al., (2004) invariably the representatives that are responsible for controlling the defects process may belong to the same bodies with the project manager that acts as the controller of the overall quality process.

Therefore measures and processes need to be put in place that encourage not only best practice but identify opportunities where improvements could be made to forestall defects in building construction.

Craig (2008) identified two useful opportunity points where building inspection processes could be enhanced for overall building construction performance in the UK. The first opportunity point is during building construction when 'absorbed defects' are picked up by the builder or during council inspections. With proper attention to performance details, it is possible for these 'absorbed defects' to be corrected during construction before practical completion of buildings.

The next opportunity point for building inspection is at hand-over of newly constructed buildings to new owners. Defects noticed at this stage are referred to as 'visible defects' (Craig, 2008). Visible defects are those which are usually detected by the homeowners after the built facility has been purchased. These are the category of defects 
that become burdens to a homeowner assuming that absorbed defects would have been taken care of through the building inspection stages outlined in building consent processes.

Sommerville, Craig and Ambler (2005) explain that these opportunity points present potentials for cost savings and process improvement in residential construction. For example, builders would have to absorb rectification costs which reduce their potential profit during construction, while at hand-over visible defects deplete profit further and are burdensome to homeowners.

The fact that building inspection are mostly carried out for old and existing buildings in New Zealand, means that there is a missed opportunity for capturing defects that occur at hand-over of new buildings.

House sales and purchase contracts are often conditional on the issuance of a Code Compliance Certificate (CCC) (Gibson, 2010). This wrongfully assumes that staged council inspections during construction would have identified defective works, which would have been rectified before the issuance of a CCC. Absorbed defects are the ones that are mostly noticed by either the developer or council inspectors during the construction process, and are more technical in nature. Whereas homeowners are more concerned with aesthetic items (visible defects). Visible defects are damaging to the image of house builders and detract from customer satisfaction because very often they never get rectified once the builder is gone. Therein lays the opportunities for the use of independent building inspection (snagging) in new residential buildings in New Zealand.

\section{Conclusion}

The objective of this paper is to show that quality performance is an issue in residential construction and that there is need for improvement. This has been achieved by reviewing literature that provided invaluable insights into building defects and identifying areas where building inspection could improve building production processes.

The literature evaluation shows that snagging is common practice for new builds in the UK, which helps in the identification of performance improvement areas for its builders. It is hoped that New Zealand could benchmark these quality improvement opportunities in its own residential sector.

The measure of quality achievement lies on the perception of the end-user. Homeowners want a product that is defect free and worth the utmost value for their investment. Quality of finish can often be overlooked during the buying process, but once a buyer has moved in, perceived problems can grow out of all proportion to affect the overall performance of the new home. We therefore conclude that there are opportunities for the use of independent building inspection for defect identification at hand-over of new residential buildings in New Zealand. The more the checks and inspection on building performance, the more probable the final build will meet required quality standards.

\section{Acknowledgments}

The authors wish to acknowledge Building Research Levy, New Zealand who provided funding for this research programme.

\section{References}

Abdul-Rahman, H. (1995). The cost of nonconformance during a highway project: A case study. Construction Management and Economics, 13, 23-32.

Abdul-Rahman, H. (1997). Some observations on the issue of quality cost in construction. Quality and Reliability Management, 14(5), 464-481.

Alan, N., Yin, Y., \& Scheepbouwer, E. (2008). A study into the cyclical performance of the New Zealand construction industry Journal for Emerging Issues in the Construction Industry (10). 
Atkinson, A. A. (2002). The pathology of building defects: A human error approach. Engineering Construction and Architectural Management, 9(1), 53-61.

Auchterlounie, A., \& Hinks, J. (2001. The measurement of customer satisfaction in the private house building sector. Paper presented at the meeting of the COBRA RICS Annual Conference, RICS, Glasgow.

Barber, P., Graves, A., Hall, M., Sheath, D., \& Tomkins, C. (2000). Quality failure costs in civil engineering projects. Quality and Reliability Management, 17(4/5), 479-492.

Beattie, K. (2011). The inspection process for defects within the New Zealand residential building industry. Auckland University of Technology, Auckland.

Building and Construction Sector Productivity Taskforce. (2009). A modern efficient and productive New Zealand built infrastructure industry. New Zealand.

CIC. (2004). Best practice procurement in construction and infrastructure in New Zealand Construction Industry Council, New Zealand.

Cossar, C. (2003, January 25). Check it out. New Zealand Herald.

Craig, N. (2008). The prevailing trend of defects and snagging in new homes in the $\mathrm{UK}(\mathrm{PhD}$ Thesis). Glasgow Caledonia University Glasgow.

Fayek, A. R., Dissanayake, M., \& Campero, O. (2004). Developing a standard methodology for measuring rework and classifying construction field rework. Canadian Journal of Civil Engineering 31(6), 1077-1089.

Georgiou, J. (2000). A Comparison of defects in houses constructed by owners and registered builders in Victoria 1988-1996 (Master's thesis). Deaken University, Geelong - Australia.

Griffith, A. (1990). Quality assurance in building. London: Macmillan.

Hunn, D. (2002). Report of the overview group on the weathertightness of building to building industial authority. New Zealand.

Ilozor, B. D., Okoroh, M. I., \& Egbu, C. E. (2004). Understanding residential house defects in
Australia from the state of Victoria. Building and Environment, 39(3), 327-337.

Josephson, P. E., \& Hammarlund, Y. (1999). The cost and cause of defects in construction: A study of seven building projects. Automation in Construction, 8(6), 681-687.

Love, P. E. D., \& Li, H. (2000). Quatifying the causes and costs of rework in construction. Construction Management and Economics, 18, 479-490.

Love, P. E. D., \& Sohal, A. S. (2003). Capturing rework cost in projects Managerial Auditing, 18(4), 329-339.

Mills, A., Love, P., E. D, \& Williams, P. (2009). Defect cost in residential construction. Construction Engineering and Management, 1(12), 12-16.

Page, I. C. (2011, April/May). Defects in new houses. Build 123, 37.

Pedro, J. B., Meijer, F., \& Visscher, H. (2008. Analysis of the Portuguese building regulation system. Paper presented at the meeting of the COBRA 2008, Dublin Institute of Technology.

Roy, R., \& Cochrane, S. P. (1998). Development of a customer focused strategy in speculative house building. Construction Management and Economics, 17, 777-787.

Sommerville, J. (2007). Defects and rework in new build: An analysis of the phenomenon and drivers. Structural Survey, 25(5), 391-407.

Sommerville, J., Craig, N. \& Ambler, V. (2005, 48 July). Managing the snagging process Symposium conducted at the meeting of the COBRA RICS Annual Conference, Queensland University of Technology, Brisbane.

Sommerville, J., Craig, N., \& Bowden, S. (2004). The standardisation of construction snagging. Structural Survey, 22(5), 251-258.

Sommerville, J., \& McCosh, J. (2006). Defects in new homes: An analysis of data on 1,696 new UK houses. Structural Survey, 24(1), 6-21. 